\title{
A Specific Inhibitor of Complement (C5)-Derived Chemotactic Activity in Serum from Patients with
}

\section{Systemic Lupus Erythematosus}

\author{
H. Daniel Perez, Mark Lipton, and Ira M. Goldstein, Department of Medicine, \\ Division of Rheumatology, New York University Medical Center, New York 10016
}

A B S T RACT In the course of examining polymorphonuclear leukocyte (PMN) chemotaxis in patients with systemic lupus erythematosus (SLE), we have found a previously undescribed serum inhibitor of complement (C5)-derived chemotactic activity. Serum from a 25-yr-old Black female with untreated SLE, when activated with zymosan, failed completely to attract either her own or normal PMN. Incubation of normal PMN with the patient's serum did not affect their subsequent random motility or chemotactic response toward normal zymosan-treated serum (ZTS). The patient's serum, however, did inhibit the chemotactic activity of normal ZTS and of column-purified C5-derived peptide(s), but had no effect on the chemotactic activity of either the synthetic peptide, $N$-formylmethionyl leucyl-phenylalanine or a filtrate prepared from a culture of Escherichia coli (bacterial chemotactic factor). The inhibitory activity in the patient's serum resisted heating at $56^{\circ} \mathrm{C}$ for $30 \mathrm{~min}$ and could be separated from $\mathrm{C5}$-derived chemotactic activity in the patient's ZTS (or normal ZTS that had been incubated with the patient's serum) by chromatography on Sephadex G-75. Despite its effect on C5-derived chemotactic activity, the patient's serum did not influence two other C5-derived biologic activities: PMN lysosomal enzyme-releasing activity and PMN-aggregating activity. Chromatography of the patient's serum $(65 \%$ ammonium sulfate pellet) on Sephadex G-200 yielded three distinct peaks of inhibitory activity. Two were

This work was presented in part at the Eastern Section Meeting of the American Federation for Clinical Research, Boston, Mass., January 1978, and published in abstract form in 1977. Clin. Res. 25: 664A. (Abstr.)

Dr. Perez was supported by a training grant from the $\mathrm{Na}$ tional Institutes of Health (AM-07176) and by a Clinical Research Center grant from the Arthritis Foundation. Dr. Goldstein is the recipient of a Career Scientist Award from the Irma T. Hirschl Trust.

Received for publication 19 December 1977 and in revised form 6 March 1978. heat labile and exhibited other properties of the previously described chemotactic factor inactivators of normal human serum. The third and most active peak, however, resisted heating at $56^{\circ} \mathrm{C}$ for $30 \mathrm{~min}$, eluted with an apparent mol wt of 50,000-60,000, and acted specifically on C5-derived chemotactic activity. This uniquely specific, heat-stable inhibitor of C5-derived chemotactic activity has been found thus far in serum from 4 of 11 patients with active SLE and may account, in part, for altered host defenses against infections caused by pyogenic microorganisms.

\section{INTRODUCTION}

Infection is a major cause of morbidity and mortality among patients with systemic lupus erythematosus $(\mathrm{SLE})^{1}(1-4)$. Whereas treatment with adrenal corticosteroids is undoubtedly a contributing factor $(3,4)$, there is also considerable evidence that the disease per se is associated with abnormalities of host defenses against infection. Staples et al. (4), for example, have reported that the incidence of infections among patients with SLE was 10-fold greater than that observed in patients with rheumatoid arthritis and 5-fold greater than that observed in a group of patients with nephrotic syndrome receiving comparable steroid therapy. Furthermore, the infection rate for patients with SLE not receiving steroid therapy was four times that observed in similarly treated patients with other diseases. The majority of infections that occur in patients with SLE are caused by pyogenic bacteria $(3,4)$. Consequently, investigators have begun to examine some of the major mechanisms of defense against such infections in pa-

\footnotetext{
'Abbreviations used in this paper: C, complement; EGTA, ethylene glycol-bis (beta-aminoethyl ether) N,N'-tetra-acetic acid; $N$-formyl-metleu-phe, $N$-formylmethionylleucylphenylalanine; PMN, polymorphonuclear leukocyte(s); RBC, erythrocytes; SLE, systemic lupus erythematosus; ZTS, zymosan-treated serum.
} 
tients with SLE. Particular attention has been directed at the complement system and the function of peripheral blood polymorphonculear leukocytes (PMN) (5-10).

PMN are essential to normal host defenses by virtue of their ability to seek out, recognize, ingest, and kill invading microorganisms (11). This requires a series of discrete steps; the first of which is directed migration (chemotaxis) of the cells toward invading pathogens. Such directed migration of PMN is mediated largely by those fluid-phase components of the complement system that are generated after activation of either the classic or alternative complement pathways $(12,13)$.

Abnormalities of PMN chemotaxis have already been reported in some patients with SLE. For example, PMN from a small number of untreated patients have been found to migrate abnormally toward standard chemotactic stimuli $(7,9)$. In contrast to this apparent cellular abnormality, Clark et al. (10) have found reduced complement-derived chemotactic activity in endotoxin-activated serum from 10 of 23 patients with SLE. PMN from all of these patients appeared to migrate normally toward a standard complement-derived stimulus. The precise nature of the abnormality observed in sera from these patients was not determined. Reduced chemotactic activity in endotoxin-activated serum could result either from a defect in the complement system (e.g. deficiency of one or more components) from which this activity is derived or to inactivators (or inhibitors) of chemotactic factors. Whereas the former possibility was investigated to some extent by these authors (and excluded), the latter was not.

In the course of examining PMN chemotaxis in patients with SLE, we also have encountered abnormalities of complement-derived chemotactic activity in some activated sera ( 5 of 11 sera studied). As an explanation for some of these abnormalities, we have found in four of these sera a uniquely specific, reversible inhibitor of complement (C5)-derived chemotactic activity. Some of the properties of this inhibitor are described in this report.

\section{METHODS}

Preparation of leukocyte suspensions and sera. Venous blood $(32 \mathrm{ml})$ from healthy adult donors and from patients with SLE was allowed to sediment at room temperature after mixing with $8.0 \mathrm{ml}$ acid-citrate dextrose (National Institutes of Health formula A) and $20 \mathrm{ml} 6.0 \%$ dextran (average mol wt 234,000) (Sigma Chemical Co., St. Louis, Mo.) in $140 \mathrm{mM}$ $\mathrm{NaCl}$. $35 \mathrm{ml}$ of $0.87 \% \mathrm{NH}_{4} \mathrm{Cl}$ was added to $15-\mathrm{ml}$ aliquots of the leukocyte-rich supernates, and the mixtures were centrifuged at $155 \mathrm{~g}$ for $10 \mathrm{~min}$. Pellets were washed once with $140 \mathrm{mM} \mathrm{NaCl}$ and finally suspended in phosphate-buffered saline (Dulbecco's phosphate-buffered saline, Grand Island Biological Co., Grand Island, N. Y.) supplemented with 0.6 $\mathrm{mM} \mathrm{CaCl}, 1.0 \mathrm{mM} \mathrm{MgCl}_{2}$, and $2.0 \%$ (wt/vol) bovine serum albumin (Grand Island Biological Co.), and adjusted to pH 7.4. This buffer was used throughout. Cell suspensions contained approximately $85 \%$ PMN.
Venous blood from normal volunteers and patients with SLE was allowed to clot at room temperature. Serum obtained after centrifugation was either used fresh or stored in aliquots at $-70^{\circ} \mathrm{C}$.

The criteria for diagnosis of SLE were those of the American Rheumatism Association (14). Clinical manifestations, such as fever, skin rash, arthritis, serositis, and glomerulonephritis, were used to arrive at the diagnosis of SLE activity. All of the patients studied had active disease by these criteria. None, however, was infected or azotemic at the time of study.

Chemotactic factors. C5-derived chemotactic activity was generated in fresh or frozen $\left(-70^{\circ} \mathrm{C}\right)$ serum by adding zymosan (1.0 mg/ml; ICN Nutritional Biochemicals Div., International Chemical and Nuclear Corp., Cleveland, Ohio) (15). After 15 min of incubation at $37^{\circ} \mathrm{C}$, the zymosan-serum suspension was centrifuged at $3,000 \mathrm{~g}$ for $10 \mathrm{~min}$. The particle-free supernate was either used directly (diluted with buffer as indicated for each experiment) or chromatographed in a $2.6 \times 40-\mathrm{cm}$ column of Sephadex G-75 (Pharmacia Fine Chemicals, Piscataway, N. J.) employing phosphate $(10 \mathrm{mM})$-buffered $140 \mathrm{mM}$ $\mathrm{NaCl}, \mathrm{pH} 7.4$, as the eluant. Filtration was performed at $4^{\circ} \mathrm{C}$ at a rate of $10 \mathrm{ml} / \mathrm{h}$. Fractions were assayed for C5-derived chemotactic activity, as previously described $(15,16)$, and those with peak activity were employed in the experiments described below. The bulk of evidence regarding the identity of the chemotactic activity generated in zymosan-treated serum (ZTS) and isolated by Sephadex G-75 chromatography indicates that it is a low molecular weight (approximately 17,000 daltons) product of C.5 $(15,16)$. The chemotactic activity is resistant to heat $\left(56^{\circ} \mathrm{C}\right.$ for $\left.30 \mathrm{~min}\right)$ and is inhibitable by antibodies to human C5, but not by those to human C.3. The protein content of fractions was determined by the method of Lowry et al. (17).

Other chemoattractants included the synthetic peptide, $\mathrm{N}$ formyl-methionylleucylphenylalanine ( $N$-formyl-met-leu-phe; Peninsula Laboratories, Inc., San Carlos, Calif.) $(18,19)$ and bacterial chemotactic factor from Escherichia coli. The latter was prepared by the method described by Ward et al. (20).

PMN chemotaxis. PMN random motility and directed migration (chemotaxis) were assessed by employing the "leading front" method of Zigmond and Hirsch (21). Aliquots $(0.8 \mathrm{ml})$ of leukocyte suspensions (containing $2.5 \times 10^{6} \mathrm{PMN} / \mathrm{ml}$ ) were added to the upper compartments of modified Boyden chambers (Nucleopore Corp., Pleasanton, Calif.). These were separated from the lower compartments (containing buffer or dilutions of chemoattractants) by $3.0-\mu \mathrm{m}$ (pore diameter) cellulose nitrate micropore filters (Sartorius, Filters, Inc., San Francisco, Calif.). Chambers containing cells and chemoattractants were incubated at $37^{\circ} \mathrm{C}$ for $45 \mathrm{~min}$ in an atmosphere of $5 \% \mathrm{CO}$. and $100 \%$ humidity. The filters were then removed, fixed in methanol, stained with hematoxylin, dehydrated in ethanol, and cleared in xylene. The response of PMN either to buffer alone (random motility) or to chemotactic stimuli is reported as the distance the leading front of cells migrated into the filter (micrometers/45 min). Triplicate chambers were employed in each experiment and 10 fields were examined in each filter.

For experiments in which unactivated serum was added to the lower compartments of the modified Boyden chambers, concentrations were chosen that did not by themselve's enhance PMN migration in excess of that observed when albumin-containing buffer was employed alone. Thus, there was no further enhancement of the chemokinetic effect of albumin in this experimental assay system $(21,22)$.

Lysosomal enzyme release from PMN. Lysosomal enzyme release from cytochalasin B-treated PMN exposed to ZTS was measured as previously described $(15,23)$. Alicuots $(0.5 \mathrm{ml})$ of leukocyte suspensions containing $4 \times 10^{6} \mathrm{PMN}$ were dis- 
pensed into $10 \times 75-\mathrm{mm}$ polypropylene tubes. Cells were preincubated with cytochalasin B $(5.0 \mu \mathrm{g} / \mathrm{ml})$ (ICI Research Laboratories, Alderley Park, Cheshire, Eng.) in 0.1\% dimethyl sulfoxide (Matheson, Coleman \& Bell, East Rutherford, N. J.) at $37^{\circ} \mathrm{C}$ for $10 \mathrm{~min}$ before addition of ZTS. This concentration of dimethyl sulfoxide did not influence enzyme release or enzyme assays. After incubation for $60 \mathrm{~min}$ at $37^{\circ} \mathrm{C}$, the tubes were centrifuged at $755 \mathrm{~g}$ for $10 \mathrm{~min}$ and the cell-free supernates removed for enzyme assays. Activity in these supernates of the lysosomal marker enzyme, beta glucuronidase was determined after $18 \mathrm{~h}$ of incubation with phenolphthalein glucuronidate (Sigma Chemical Co.) as substrate (24). The cytoplasmic enzyme, lactate dehydrogenase was determined by the method of Wacker et al. (25). Release of lactate dehydrogenase was used as an indicator of cell viability $(15,23)$. Enzyme activity released into supernates during the experimental period is expressed as percent of the total activity recoverable from simultaneously run duplicate reaction mixtures to which had been added the detergent, Triton X-100 $(0.2 \% \mathrm{vol} / \mathrm{vol})$ (Rohm and Haas Co., Philadelphia, Pa.). All values were corrected for background enzyme activity in medium blanks.

PMN aggregation. Aggregation of PMN by ZTS was measured as previously described $(26,27)$. For these experiments, purified preparations of PMN were obtained by means of Ficoll-Hypaque gradients (Pharmacia Fine Chemicals) (28). Reaction mixtures consisted of $1 \times 10^{7} \mathrm{PMN}$, cytochalasin B $(5.0 \mu \mathrm{g} / \mathrm{ml})$, and serum in a volume of $1.0 \mathrm{ml}$. Aggregation (change in light transmission, $\Delta \mathrm{T}$ ) was recorded with a standard platelet aggregometer/recorder system (model $300 \mathrm{BD}$, Payton Associates, Buffalo, N. Y.). The recorder was calibrated at maximal light transmission with a $50 \%(\mathrm{vol} / \mathrm{vol})$ dilution of the PMN suspension. Experiments were performed in siliconized cuvettes at $37^{\circ} \mathrm{C}$ and at a stirring speed of $900 \mathrm{rpm}$.

Alternative complement pathway activation in serum. Normal human erythrocytes (RBC) were rendered susceptible to complement-mediated lysis by treatment with dithiothreitol (Sigma Chemical Co.) $(29,30)$. Venous blood from normal volunteers was defibrinated in 12.5-ml Erlenmeyer flasks containing glass beads. After centrifugation at $100 \mathrm{~g}$ for $15 \mathrm{~min}$, the supernate and buffy coat were removed. The RBC were then washed three times in phosphate $(10 \mathrm{mM})$-buffered saline, $\mathrm{pH}$ 8.0. Approximately $2.0 \mathrm{ml}$ of packed $\mathrm{RBC}$ was then added to $8.0 \mathrm{ml} 0.2 \mathrm{M}$ dithiothreitol in the same buffer and incubated for $20 \mathrm{~min}$ at $37^{\circ} \mathrm{C}$. The $\mathrm{RBC}$ were then washed repeatedly with buffer until the supernate was clear of the hemoglobin. The washed $\mathrm{RBC}$ were finally suspended in Veronal-buffered saline, $\mathrm{pH}$ 7.4. Reaction mixtures containing $\mathrm{RBC}, 10 \mathrm{mM}$ ethylene glycol-bis $\left(\beta\right.$-aminoethyl ether) $N, N^{\prime}$ tetraacetic acid (EGTA), $10 \%(\mathrm{vol} / \mathrm{vol})$ serum, and other additions in a final volume of $0.5 \mathrm{ml}$ were incubated at $37^{\circ} \mathrm{C}$ for $30 \mathrm{~min}$ and then centrifuged at $1,000 \mathrm{~g}$ for $10 \mathrm{~min}$ at $4^{\circ} \mathrm{C}$. Cell-free supernates were assayed for hemoglobin with Drabkin's solution as previously described (29). Results are expressed as the percent of total hemoglobin released into supernates from reaction mixtures containing $0.1 \%$ Triton $\mathrm{X}-100$.

Other compounds and reagents. "Pronase" (protease from Streptomyces griseus) and trypsin were obtained as insoluble enzymes attached to carboxymethyl cellulose and polyacrylamide, respectively (Sigma Chemical Co.). Compounds used for calibration of Sephadex columns were obtained from Pharmacia Fine Chemicals, Inc. (blue dextran) and Sigma (hemical Co. (ovalbumin, cytochrome $c$ ).

\section{RESULTS}

Abnormalities of chemotactic activity in zymosantreated SLE sera. Sera obtained from 11 patients with
SLE were activated with zymosan and examined for chemotactic activity. ZTS from five of these patients failed to attract PMN comparably to normal ZTS (see below). ZTS from one of these patients (R. J.), a 25yr-old Black female with newly diagnosed untreated SLE, failed completely to attract normal PMN (Table I). Migration toward R. J. ZTS did not exceed that observed when only buffer containing albumin was added to the lower compartments of the modified Boyden chambers (random motility). To exclude the possibility that this apparent absence of chemotactic activity in R. J. ZTS was due to the presence of an irreversible inhibitor of cell motility, normal PMN were incubated with R. J. serum for $30 \mathrm{~min}$ at $37^{\circ} \mathrm{C}$, washed with buffer, and examined for chemotactic responsiveness. As can be seen in Table I, such treatment of normal PMN did not affect their subsequent random motility or chemotactic response toward normal ZTS. Furthermore, the patient's own PMN were capable of migrating in a directed fashion toward the same stimulus. As was the case with normal PMN, however, R. J. PMN exhibited only random motility in response to R. J. ZTS.

Complement activation in normal vs. R. J. serum. Inasmuch as levels of C3 and C4 (measured immunochemically) in R. J. serum were modestly reduced ( 72 and $8 \mathrm{mg} / \mathrm{dl}$, respectively), it was possible that the apparent absence of chemotactic activity in R. J. ZTS was due either to a deficiency of one or more com-

TABLE I

Absence of Chemotactic Activity in R. J. ZTS

\begin{tabular}{|c|c|c|c|}
\hline \multicolumn{2}{|r|}{ Additions to } & \multirow[b]{2}{*}{$n$} & \multirow[b]{2}{*}{$\begin{array}{c}\text { PMN } \\
\text { migration }\end{array}$} \\
\hline $\begin{array}{c}\text { Upper } \\
\text { compartment }\end{array}$ & Lower compartment & & \\
\hline & & & $\begin{array}{c}\mu m / 45 \\
\min \pm S E\end{array}$ \\
\hline \multirow{3}{*}{ Normal PMN } & Buffer (random motility) & 5 & $82.4 \pm 1.6$ \\
\hline & Normal ZTS* & 5 & $123.5 \pm 6.1 \neq$ \\
\hline & R. J. ZTS & 5 & $78.9 \pm 2.5 \S$ \\
\hline \multicolumn{4}{|l|}{$\begin{array}{l}\text { Normal PMN } \\
+ \text { R. J. }\end{array}$} \\
\hline serum" & Normal ZTS & 2 & $119.5 \pm 3.1$ \\
\hline \multirow{3}{*}{ R. J. PMN } & Buffer & 2 & $81.7 \pm 1.8$ \\
\hline & Normal ZTS & 2 & $118.8 \pm 3.4$ \\
\hline & R. J. ZTS & 2 & $80.8 \pm 1.6$ \\
\hline
\end{tabular}

*ZTS was employed at a concentration of $10 \%(\mathrm{vol} / \mathrm{vol})$ PMN and normal serum were obtained from five different donors; $n=$ number of experiments.

$\$ P$ vs. random motility $<0.001$ (Student's $t$ test).

$\S P$ vs. random motility $>0.1$ (Student's $t$ test).

"Normal PMN from two different donors were incubated with $10 \%(\mathrm{vol} / \mathrm{vol})$ R. J. serum $\left(37^{\circ} \mathrm{C}\right.$ for $\left.30 \mathrm{~min}\right)$ and washed twice with buffer. 
TABLE II

Complement Activation in Normal vs. R. J. Serum

\begin{tabular}{lcc}
\hline \multicolumn{1}{c}{ Additions to dithiothreitol-treated RBC $^{*}$} & $n$ & Hemolysis $!$ \\
\hline & & $\%$ \\
Normal serum & 3 & $3.4 \pm 0.9$ \\
R. J. serum & 3 & $3.6 \pm 1.1$ \\
Normal serum + zymosan, $1.0 \mathrm{mg} / \mathrm{ml}$ & 3 & $39.6 \pm 2.5 \S$ \\
R. J. serum + zymosan & 3 & $42.3 \pm 3.0 \S$ \\
\hline
\end{tabular}

* See Methods. Reaction mixtures contained 10 mM EGTA. Expressed as percent of total hemoglobin released $( \pm \mathrm{SE})$ by $0.1 \%(\mathrm{vol} / \mathrm{vol})$ Triton $\mathrm{X}-100 ; n=$ number of experiments. $\$ P$ vs. serum alone $<0.001$ (Student's $t$ test).

plement components or to an abnormality of complement activation, as consequences of her disease. This possibility was explored by measuring alternative complement pathway activation by zymosan in EGTAtreated normal vs. R. J. serum. As targets, we employed unsensitized RBC rendered susceptible to complement-mediated lysis by treatment with dithiothreitol $(29,30)$. Addition of zymosan to EGTA-treated R. J. serum caused hemolysis comparable to that observed when EGTA-treated normal serum was employed as a source of complement (Table II). Thus, no gross abnormalities of alternative complement pathway activation by zymosan in $R$. J. serum could be detected.

Effect of R. J. serum on chemotactic activity in normal ZTS. Incubation for $30 \mathrm{~min}$ at $37^{\circ} \mathrm{C}$ of normal ZTS with either fresh or heated $\left(56^{\circ} \mathrm{C}\right.$ for $\left.30 \mathrm{~min}\right)$ normal serum had no effect on chemotactic activity (Table III). Similar treatment with R. J. serum (fresh or heated), however, resulted in a dose-dependent diminution of chemotaxis (Table III and Fig. 1). As little

TABLE III

Effect of Normal vs. R. J. Serum on Chemotactic Activity in ZTS

\begin{tabular}{llr}
\hline \multicolumn{1}{c}{ Stimulus } & $n$ & PMN migration \\
\hline & & $\mu m / 4.5$ min $\pm S E$ \\
Buffer (random motility) & 3 & $82.2 \pm 1.1$ \\
Normal ZTS & 3 & $114.7 \pm 4.3$ \\
$\quad$ + normal serum* & 2 & $116.6 \pm 5.5$ \\
+ normal serum (heated) & 2 & $115.8 \pm 3.7$ \\
+ R. J. serum* & 3 & $82.7 \pm 0.7$ \\
+ R. J. serum (heated)* & 3 & $81.1 \pm 0.3$ \\
Normal ZTS + R. J. serum $\$$ & 2 & $116.1 \pm 2.4$ \\
\hline
\end{tabular}

* ZTS was preincubated with fresh or heated $\left(56^{\circ} \mathrm{C}\right.$ for 30 min) serum $(1: 1, \mathrm{vol} / \mathrm{vol})$ at $37^{\circ} \mathrm{C}$ for $30 \mathrm{~min}$. Final concentration of ZTS was adjusted to $3.0 \%(\mathrm{vol} / \mathrm{vol})$ before addition to stimulus compartment; $n=$ number of experiments. ‡ ZTS was mixed (1:1) with R. J. serum without preincubation and employed as described above. as $5.0 \mu \mathrm{l}$ of R. J. serum was capable of causing significant inhibition of chemotactic activity when preincubated with $100 \mu$ l of normal ZTS. When R. J. serum was added to normal ZTS without preincubation, however, no inhibition of chemotaxis was observed. Thus, it was possible to distinguish further between an effect of R. J. serum on the chemotactic activity in normal ZTS vs. an effect on the PMN.

Specificity of inhibitory activity in R. J. serum. In contrast to the effect of $R$. J. serum on the chemotactic activity in normal ZTS, no inhibitory effect was observed when this serum was incubated with various concentrations (all suboptimal) of either the bacterial chemotactic factor from E. coli or the chemotactic synthetic peptide, $N$-formyl-met-leu-phe (Table IV). R. J. serum did, however, inhibit the activity of the chemotactic C5-derived peptide obtained after Sephadex G75 chromatography of normal ZTS.

Reversibility of the inhibitory effect of R. J. serum on C5-derived chemotactic activity. Normal ZTS and R. J. ZTS were subjected to molecular sieve chromatography on Sephadex G-75. Fractions were assayed for chemotactic activity and for inhibitory activity (by incubation with fresh normal ZTS) (Fig. 2). As expected, normal ZTS yielded a major peak of chemotactic activity in the molecular weight range of 15,000-20,000 daltons (Fig. 2A). This peak corresponded to C5-derived chemotactic activity as evidenced by resistance to heating at $56^{\circ} \mathrm{C}$ for $30 \mathrm{~min}$ and susceptibility to inactivation by antibody to human C $5(15,16)$. Identical C5-derived chemotactic activity was recovered when R. J. ZTS (originally devoid of such activity, see Table I) was chromatographed. Chromatography of R. J. ZTS also yielded inhibitory activity in fractions eluting with the void volume (solid bars in Fig. 2B). No such inhibitory activity was recovered from normal ZTS (Fig. 2a). Thus, we were able to separate inhibitory from chemotactic activity in R. J. ZTS.

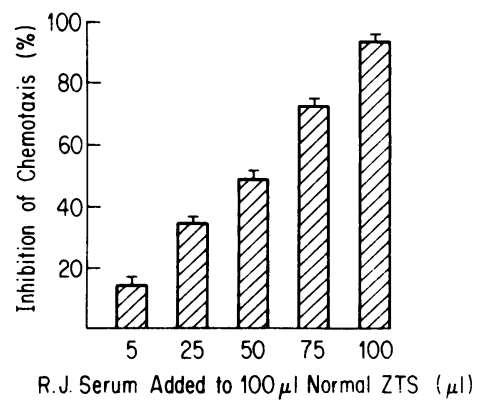

FIGURE 1 Inhibition by R. J. serum of chemotactic activity in normal ZTS. Normal ZTS $(100 \mu \mathrm{l})$ was preincubated at $37^{\circ} \mathrm{C}$ for $30 \mathrm{~min}$ with various amounts of R. J. serum before addition to stimulus compartment. Final concentration of ZTS was $10 \%(\mathrm{vol} / \mathrm{vol})$. In the absence of R. J. serum, PMN migration was $148.0 \mu \mathrm{m} / 45 \mathrm{~min}$. Random motility ( $100 \%$ inhibition of chemotaxis) was $82.0 \mu \mathrm{m} / 45 \mathrm{~min}$. 
TABLE IV

Specificity of Inhibitory Activity in R. J. Serum

\begin{tabular}{|c|c|c|c|}
\hline \multirow[b]{2}{*}{ Stimulus } & \multirow[b]{2}{*}{$n$} & \multicolumn{2}{|c|}{ PMN migration } \\
\hline & & Normal serum* & R. J. serum* \\
\hline & & \multicolumn{2}{|c|}{$\mu m / 45 \min \pm S E$} \\
\hline Buffer (random motility) & 3 & $92.0 \pm 0.8$ & $90.5 \pm 0.9$ \\
\hline Bacterial chemotactic factor $\begin{array}{l}(3.0 \%, \mathrm{vol} / \mathrm{vol}) \\
(2.0 \%, \mathrm{vol} / \mathrm{vol})\end{array}$ & $\begin{array}{l}3 \\
3\end{array}$ & $\begin{array}{l}112.5 \pm 0.7 \\
102.1 \pm 0.8\end{array}$ & $\begin{array}{l}113.3 \pm 0.7 \\
102.8 \pm 0.8\end{array}$ \\
\hline$N$-formyl-met-leu-phe $(10 \mathrm{nM})$ & $\begin{array}{l}2 \\
2\end{array}$ & $\begin{array}{l}123.7 \pm 0.9 \\
102.7 \pm 0.7\end{array}$ & $\begin{array}{l}122.2 \pm 0.8 \\
102.3 \pm 0.8\end{array}$ \\
\hline C.5-derived chemotactic peptidet $\begin{array}{l}(4.8 \mu \mathrm{g} / \mathrm{ml}) \\
(2.4 \mu \mathrm{g} / \mathrm{ml})\end{array}$ & $\begin{array}{l}3 \\
3\end{array}$ & $\begin{array}{l}144.0 \pm 1.0 \\
123.1 \pm 0.9\end{array}$ & $\begin{array}{l}114.2 \pm 0.8 \\
101.3 \pm 1.2\end{array}$ \\
\hline
\end{tabular}

* Stimuli were preincubated with either heated $\left(56^{\circ} \mathrm{C}\right.$ for $\left.30 \mathrm{~min}\right)$ normal serum or heated R. J. serum $(1: 1, \mathrm{vol} / \mathrm{vol})$ at $37^{\circ} \mathrm{C}$ for $30 \mathrm{~min}$. The final concentration of serum in the stimulus compartment was $3.0 \%(\mathrm{vol} / \mathrm{vol})$. Experiments were performed using PMN from a single donor; $n=$ number of experiments.

\ Pooled fractions after Sephadex G-75 chromatography of normal ZTS (see Methods); expressed as micrograms protein per milliliter.

Results identical to those shown in Fig. 2 were obtained when mixtures of normal ZTS plus R. J. serum or normal ZTS plus normal serum (after preincubation) were chromatographed on Sephadex G-75. The mixture of normal ZTS plus R. J. serum, which was originally devoid of chemotactic activity (Table III), yielded both

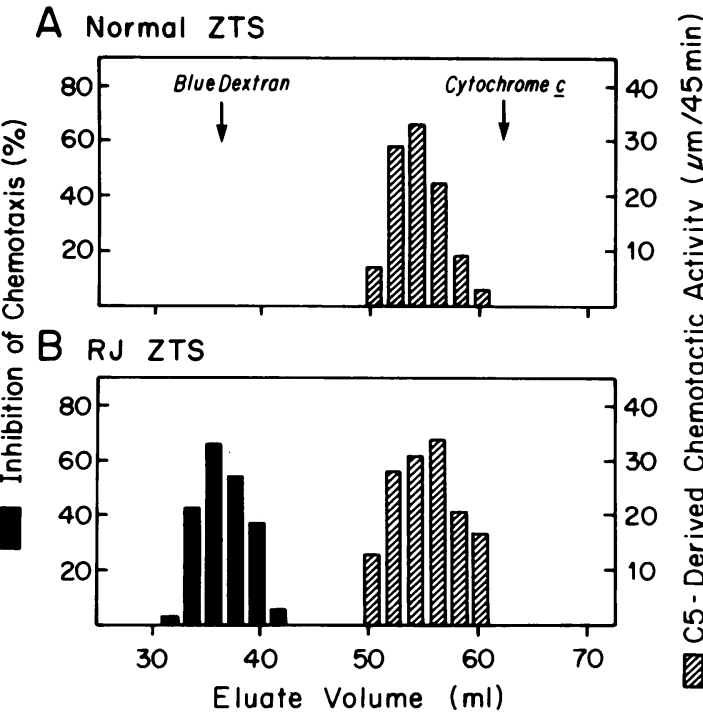

FIGURE 2 Sephadex G-75 chromatography of ZTS for chemotactic activity (hatched bars) and inhibitory activity (solid bars): (A) Normal ZTS; (B) R. J. ZTS. Aliquots of fractions were either diluted $1: 1$ ( $\mathrm{vol} / \mathrm{vol})$ with buffer to assay for chemotactic activity or were preincubated $(1: 1, \mathrm{vol} / \mathrm{vol})$ with $4.0 \%\left(\mathrm{vol} / \mathrm{vol}\right.$ ) normal ZTS at $37^{\circ} \mathrm{C}$ for $30 \mathrm{~min}$ to assay for inhibitory activity. Final concentration of ZTS was adjusted to $1.3 \%(\mathrm{vol} / \mathrm{vol})$. inhibitory and C5-derived chemotactic activity after chromatography. Normal ZTS plus normal serum yielded only chemotactic activity. Again, inhibition of C5-derived chemotactic activity by the factor(s) in R. J. serum appeared to be reversible.

Characterization of the inhibitory activity in $R$. J. serum. Stepwise fractionation of R. J. serum with ammonium sulfate yielded inhibitory activity in the $45 \%$ supernate and in the $65 \%$ pellet. The redissolved $65 \%$ ammonium sulfate pellet from R. J. serum was applied to a column $(2.6 \times 70 \mathrm{~cm})$ of Sephadex G-200 and eluted with phosphate $(10 \mathrm{mM})$-buffered $140 \mathrm{mM}$ $\mathrm{NaCl}, \mathrm{pH}$ 7.4. When fractions were assayed by incubation with normal ZTS, three distinct peaks of inhibitory activity could be discerned (Fig. 3). Inhibitory activity in peaks I and II was destroyed completely by heating at $56^{\circ} \mathrm{C}$ for $30 \mathrm{~min}$, whereas the inhibitory activity in peak III (mol wt 50,000-60,000 daltons) was resistant to this treatment. Furthermore, fractions from peak III had the same profile of inhibitory activity as whole R. J. serum. This inhibitory activity could be abolished by heating at $80^{\circ} \mathrm{C}$ for $30 \mathrm{~min}$ and by treatment with pronase $\left(0.8 \mathrm{U} / \mathrm{ml}\right.$ of insoluble enzyme for $30 \mathrm{~min}$ at $\left.37^{\circ} \mathrm{C}\right)$. It was only partially destroyed ( $30 \%$ loss of activity) by treatment with trypsin $(1.6 \mathrm{U} / \mathrm{ml}$ of insoluble enzyme for $30 \mathrm{~min}$ at $37^{\circ} \mathrm{C}$ ).

Chromatography on Sephadex G-200 of a $65 \%$ ammonium sulfate pellet of normal serum yielded only the two heat-labile peaks of inhibitory activity (Fig. 4). The properties of peaks I and II were identical to those described by Berenberg and Ward (31) for the aminopeptidase-like chemotactic factor inactivators of normal human serum. The inhibitory activity in peak III, how- 

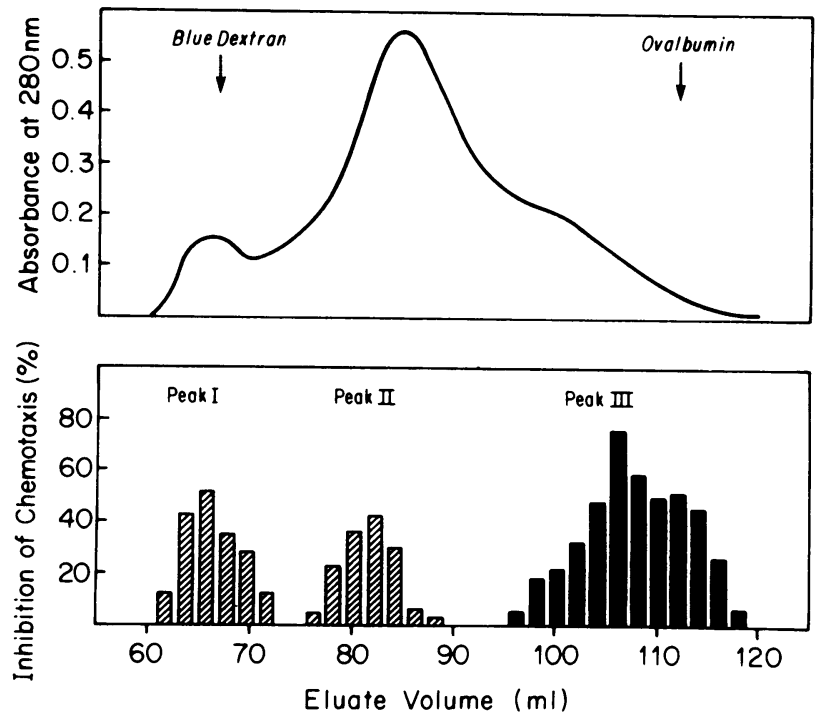

Figure 3 Sephadex G-200 chromatography of R. J. serum (65\% ammonium sulfate pellet) for inhibitory activity. Aliquots of fractions were preincubated $(1: 1, \mathrm{vol} / \mathrm{vol})$ with $4.0 \%$ (vol/vol) normal ZTS as described in Fig. 2.

ever, has not previously been described and almost certainly accounts for the inhibitory activity demonstrated in whole R. J. serum and serum from other patients with SLE (see below).

Effect of R. J. serum on other C.5-derived biologic activities in ZTS. The effect of R. J. serum on two other C.5-derived biologic activities in ZTS was examined. Addition of ZTS to cytochalasin B-treated PMN provokes the selective discharge from these cells of
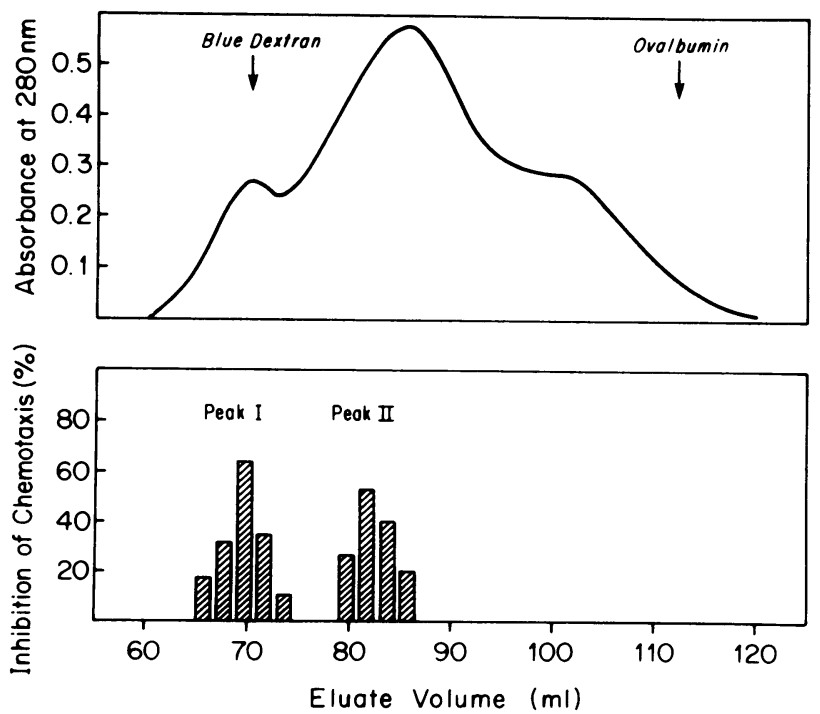

FIGURE 4 Sephadex G-20) (hromatography of normal serum (65\% ammonium sulfate pellet) for inhibitory activity (see Fig. 3). lysosomal, but not cytoplasmic, constituents $(15,23)$ and simultaneously causes PMN aggregation detectable by standard nephelometric techniques $(26,27)$. P.MN lysosomal enzyme-releasing activity and PMNaggregating activity in normal ZTS are heat stable, susceptible to inhibition by antibody to human C.5, and can be recovered after chromatography on Sephadex G-75 in the same fractions that contain C.5-derived chemotactic activity: These findings have led to the suggestion that these activities are properties of similar, if not identical, peptides cleaved from C.5 as a consequence of complement activation $(23,26)$. The effects of R. J. serum on PMN lysosomal enzyme-releasing activity and PMN-aggregating activity in normal ZTS are shown in Table $V$ and Fig. 5, respectively. In contrast to what was observed with C.5-derived chemotactic activity, neither of these other C.5-derived biologic activities was affected by R. J. serum. This was the case even when a wide range of ZTS concentrations $(1.0-10 \%, \mathrm{vol} / \mathrm{vol})$ were employed in these experiments (data not shown). Thus, the lack of inhibition by R. J. serum could not be accounted for simply by the possibility that there was a vast excess of C.5derived peptide(s) in these reaction mixtures. Moreover, R. J. ZTS, which was incapable of provoking a chemotactic response by PMN, was perfectly capable of stimulating PMN lysosomal enzyme release (Table $V$ ) and PMN aggregation (results not shown). Thus, the inhibitory activity in R. J. serum appeared to be directed specifically toward C.5-derived chemotactic activity and failed to influence at least two other biologic activities attributed to C.5-derived peptides.

Studies with sera from other patients with SLE. As indicated above, serum from R. J. and from four other

TABLE $V$

Effect of R. J. Serum on C.5-Derived PMN Lysosomal Enzyme-Releasing Activity

\begin{tabular}{lrc}
\hline \multirow{2}{*}{$\begin{array}{c}\text { Additions to cytochalasin } \\
\text { B-treated PMN }\end{array}$} & \multicolumn{2}{c}{ Total enzyme releasedt } \\
\cline { 2 - 3 } & \multicolumn{2}{c}{$\begin{array}{c}\text { Lactate } \\
\text { dehydrogenase }\end{array}$} \\
\hline & $3.1 \pm 0.6$ & $2.6 \pm 0.4$ \\
Normal serum & $3.3 \pm 0.5$ & $2.8 \pm 0.5$ \\
R. J. serum & $16.4 \pm 1.5$ & $3.1 \pm 0.6$ \\
Normal ZTS + normal serum" & \multicolumn{2}{c}{$\%$} \\
Normal ZTS + R. J. serum" & $15.5 \pm 1.3$ & $2.5 \pm 0.5$ \\
R. J. ZTS & $16.7 \pm 1.7$ & $2.9 \pm 0.4$ \\
\hline
\end{tabular}

* PMN were preincubated with cytochalasin B $(5.0 \mu \mathrm{g} / \mathrm{ml})$ at $37^{\circ} \mathrm{C}$ for $10 \mathrm{~min}$ before exposure to serum for $30 \mathrm{~min}$.

\$ Percent of total activity released by $0.2 \%$ ( $\mathrm{vol} / \mathrm{vol}$ ) Triton $\mathrm{X}-100$. Mean \pm SEM of four experiments.

"ZTS was preincubated with heated $\left(56^{\circ} \mathrm{C}\right.$ for $\left.30 \mathrm{~min}\right)$ serum $(1: 1, \mathrm{vol} / \mathrm{vol})$ at $37^{\circ} \mathrm{C}$ for $30 \mathrm{~min}$. Final concentration of ZTS was adjusted to $5.0 \%(\mathrm{vol} / \mathrm{vol})$. 


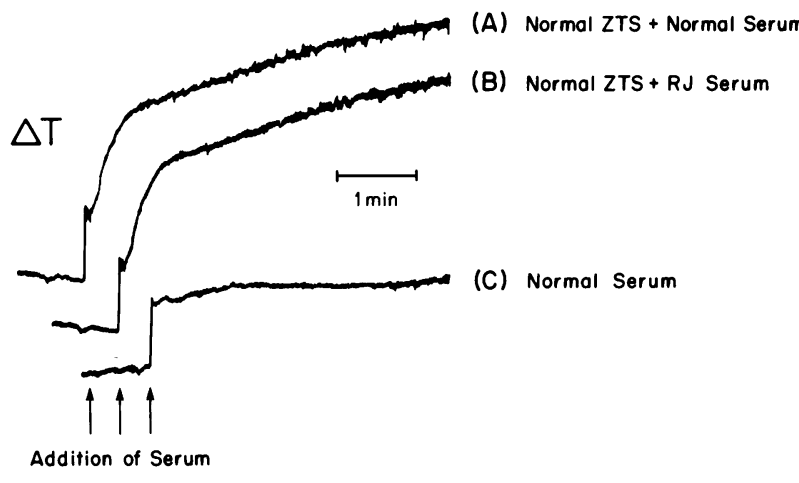

Figure 5 Effect of normal vs. R. J. serum on PMN aggregating activity in ZTS. Normal ZTS was preincubated ( $1: 1$, $\mathrm{vol} / \mathrm{vol}$ ) with either normal serum or R. J. serum at $37^{\circ} \mathrm{C}$ for $30 \mathrm{~min}$. Final concentration of ZTS was $5.0 \%$ ( $\mathrm{vol} / \mathrm{vol}$ ). (A) Normal ZTS plus normal serum; (B) normal ZTS plus R. J. serum; (C) normal serum $(5.0 \%$, vol/vol). Change in light transmission $(\Delta \mathrm{T})$ immediately upon addition of serum is dilution artifact.

patients with SLE, when activated with zymosan, failed to attract PMN comparably to normal ZTS (Table VI). These same sera were also found capable of inhibiting C5-derived chemotactic activity after incubation with normal ZTS. All but the serum obtained from patient $M$. R. retained such inhibitory activity after heating at $56^{\circ} \mathrm{C}$ for $30 \mathrm{~min}$. When these sera were examined for effects on the bacterial chemotactic factor from E. coli, only M. R. serum was found to have inhibitory activity (which was heat labile). It is very likely, therefore, that whereas M. R. serum contained only increased amounts of the previously described heat-labile chemotactic factor inactivator(s) (31-33), sera from the other four patients contained heat-stable inhibitory activity specifically directed against the C5derived chemotactic peptide(s) in ZTS. When serum from one of these patients (L. M.) was also subjected to ammonium sulfate fractionation and chromatography on Sephadex G-200, three peaks of inhibitory activity were found which were identical in every respect with the inhibitory activity isolated from R. J. serum (see Fig. 3). Obviously, too few patients with SLE were examined to determine whether the presence of such inhibitory activity correlated with any specific clinical or laboratory parameters of disease activity.

\section{DISCUSSION}

Serum from 5 of 11 patients with SLE, when activated with zymosan, attracted PMN to a lesser extent than similarly treated normal serum. These results are remarkably comparable to those previously reported by Clark et al. (10). ZTS from one patient (R. J.) failed completely to provoke a chemotactic response from either her own PMN or PMN from normal donors (Table I). Three possibilities to explain the apparent absence of C5-derived chemotactic activity in this patient's ZTS were examined. Firstly, experiments were performed to determine whether this patient's serum contained an irreversible inhibitor of PMN motility. Such inhibitors have been described previously in patients with recurrent infections $(34,35)$ and in patients with IgA myelomas (36). This possibility was excluded not only by the finding that incubation of normal PMN with the patient's serum failed to influence their subsequent random motility and chemotactic response to normal ZTS, but also by the demonstration that the patient's own PMN responded normally to this same stimulus (Table I). Moreover, R. J. serum did not influence the migration of normal PMN toward other chemotactic stimuli (Table IV).

Secondly, studies were performed to determine whether there was an abnormality of chemotactic factor generation in the patient's serum as a consequence

TABLE VI

Chemotactic Factor Inhibitory Activity in SLE Sera

\begin{tabular}{|c|c|c|c|c|c|c|}
\hline \multirow[b]{2}{*}{ Stimulus* } & \multicolumn{6}{|c|}{ PMN migration-source of serum $\downarrow$} \\
\hline & Normal & R. J. & L. $\mathbf{M}$. & P. G. & M. C. & M. $\mathbf{R}$. \\
\hline & \multicolumn{6}{|c|}{$\mu \mathrm{m} / 45 \mathrm{~min}$} \\
\hline ZTS & 131.0 & 78.9 & 118.0 & 117.6 & 115.5 & 113.3 \\
\hline Normal ZTS + serum" & 137.5 & 82.7 & 111.0 & 116.0 & 115.1 & 114.1 \\
\hline Normal ZTS + heated serum" & 131.1 & 81.1 & 114.0 & 114.4 & 116.4 & 129.5 \\
\hline Bacterial chemotactic factor + serum" & 100.0 & 101.3 & 100.4 & 108.6 & 101.5 & 84.0 \\
\hline Bacterial chemotactic factor + heated serum" & 101.5 & 102.1 & 100.8 & 106.9 & 102.4 & 102.6 \\
\hline
\end{tabular}

* ZTS and bacterial chemotactic factor were employed at final concentrations of 5.0 and $2.0 \%$ (vol/vol), respectively.

$\ddagger$ Results represent the mean of two experiments performed with PMN obtained from two different donors. Random motility was $81.5 \mu \mathrm{m} / 45 \mathrm{~min}$.

"Stimuli were preincubated with fresh or heated $\left(56^{\circ} \mathrm{C}\right.$ for $\left.30 \mathrm{~min}\right)$ serum at $37^{\circ} \mathrm{C}$ for $30 \mathrm{~min}$. 
of either a defect in complement activation or a deficiency of complement components. Whereas levels of $\mathrm{C} 3$ and $\mathrm{C} 4$ (measured immunochemically) were modestly low in the patient's serum, no major abnormalities of complement function could be detected. Studies employing RBC rendered susceptible to complement-mediated lysis by treatment with dithiothreitol, revealed no gross abnormalities in the patient's serum of either alternative complement pathway activation by zymosan or hemolytic function (Table II). Furthermore, treatment of the patient's serum with zymosan resulted in the generation of C5-derived PMN lysosomal enzyme releasing activity $(15,23)$ (Table V) and PMN aggregating activity $(26,27)$ (Fig. 5) in amounts comparable to those generated in normal serum. These latter findings suggested not only that there were no major abnormalities involving C5, but also that C5 was being cleaved to yield biologically active peptides as a consequence of activation of the alternative complement pathway by zymosan.

Finally, studies were performed to determine whether the patient's serum contained an inhibitor or inactivator of complement (C5)-derived chemotactic activity. Indeed, "mixing" experiments yielded results that were quite consistent with this possibility (Table III). Significant inhibition of chemotactic activity was observed when $5 \mu \mathrm{l}$ of R. J. serum was preincubated $\left(37^{\circ} \mathrm{C}\right.$ for $30 \mathrm{~min}$ ) with $100 \mu \mathrm{l}$ of normal ZTS (Fig. 1). That the inhibitory activity was directed against the chemotactic factor(s) in ZTS and not against the PMN was evident from the observation that mere mixing of $R$. J. serum with normal ZTS (without preincubation) failed to cause inhibition of chemotactic activity (Table III).

The inhibitory activity in $\mathrm{R}$. J. serum resisted heating at $56^{\circ} \mathrm{C}$ for $30 \mathrm{~min}$, was specific for the $\mathrm{C} 5$-derived chemotactic peptide(s) in ZTS (Table IV), and was reversible. Both inhibitory and chemotactic activities could be recovered when R. J. ZTS was chromatographed on Sephadex G-75 employing phosphate-buffered $140 \mathrm{mM} \mathrm{NaCl}$ as the eluant (Fig. 2). Separation of intact chemotactic and inhibitory activities was also obtained when mixtures of R. J. serum and normal ZTS were similarly subjected to molecular sieve chromatography.

Chromatography of R. J. serum (65\% ammonium sulfate pellet) on Sephadex G-200 yielded three distinct peaks of inhibitory activity (Fig. 3). Two were heat labile $\left(56^{\circ} \mathrm{C}\right.$ for $\left.30 \mathrm{~min}\right)$ and also inhibited the bacterial chemotactic factor (results not shown), whereas the third and most active peak (in the molecular weight range of approximately 50,000-60,000) was resistant to heating at $56^{\circ} \mathrm{C}$ for $30 \mathrm{~min}$ and inhibited only C5derived chemotactic activity. Identical results were obtained with serum from another patient (L. M.). Similarly treated normal serum, however, yielded only the two heat-labile peaks of inhibitory activity (Fig. 4).
Thus, the properties of the major inhibitory activity in whole R. J. serum (and L. M. serum) appear to be quite distinct from the properties of the previously described chemotactic factor inactivators $(31-33)$. The latter irreversibly inactivate diverse chemotactic stimuli, are of higher molecular weight, are heat labile, and are present in small amounts in normal human serum. Increased amounts of these heat-labile inactivators have been found in patients with sarcoidosis (37), Hodgkin's disease (38), hepatic cirrhosis (39), and lepromatous leprosy (40). Levels of activity in patients with SLE have not previously been reported. At least one of our SLE patients (M. R.) appeared to have increased levels of chemotactic factor inactivator(s) in her serum (Table VI). Of 11 patients examined thus far, 4 had only heat-stable inhibitory activity specifically directed at the C5-derived chemotactic peptide(s) in ZTS. Although an insufficient number of patients have been studied, preliminary observations seem to indicate a correlation between the presence of the inhibitor and disease activity. R. J. serum exhibited maximal inhibition of C5-derived chemotactic activity at the time the diagnosis of SLE was established and before any treatment was instituted. The inhibitory activity in her serum subsequently decreased by $50 \%$ after 3 mo of treatment with prednisone, at a dose of $60 \mathrm{mg} /$ day. 9 mo later, when her disease was considered to be in remission, R. J. serum failed to show any inhibitory activity. Similar results have been noted in two other patients (P. G. and L. M.).

Neither the nature of the inhibitor of C5-derived chemotactic activity in these SLE sera nor its precise mechanism of action can be determined from the studies reported here. Its specificity and failure to inactivate C5-derived chemotactic activity irreversibly suggest that it is capable of merely associating with relevant peptides rather than altering them enzymatically. Further delineation of its mechanism of action must await precise identification of the biologically active peptides derived from C5 as a consequence of complement activation. Whereas one of these peptides, the C5a anaphylatoxin, has been purified to homogeneity and demonstrated to have chemotactic and PMN lysosomal enzyme-releasing activities (41-43), it remains unclear whether this peptide accounts for the bulk of the chemotactic activity generated in whole serum by complement activation $(12,44-47)$. The possibility remains that there are a number of closely related C5-derived peptides that possess similar biologic activities, either singly or in combination.

Human C5a is rapidly converted to $\mathrm{C} \mathrm{a}_{\text {des }}$ Arg by a potent carboxypeptidase (i.e. carboxypeptidase $B$, anaphylatoxin inactivator) in serum or plasma (48). The des Arg form of C5a is inactive as an anaphylatoxin and, in the absence of other serum components, is virtually devoid of chemotactic activity (49). It is, however, chem- 
otactically active in the presence of small amounts of normal unactivated serum. These findings are similar to those of Wissler et al. (46) who described a serum "helper" factor ("cocytotaxin") required for the expression of chemotactic activity by C.5a-derived peptides. In light of these findings, it is possible that the inhibitor described above might interact with either a C5a-derived chemotactic peptide or with a "helper" factor present in serum. In this fashion, it could influence chemotactic activity in ZTS without influencing PMN lysosomal enzyme-releasing activity or PMN-aggregating activity. Whatever the mechanism may be, the presence of this inhibitor of C5-derived chemotactic activity in patients with SLE may contribute, in part, to abnormal host defenses and increased susceptibility to infection due to pyogenic microorganisms.

\section{ACKNOWLEDGMENTS}

This research was supported by grants from the National Institutes of Health (AM-18531, AM-11949, GM-23211, and HL19721), the National Foundation-March of Dimes, the National Science Foundation (76-05621), and the Whitehall Foundation.

\section{REFERENCES}

1. Dubois, E. L., M. Wierzchowiecki, M. B. Cox, and M. Weiner. 1974. Duration and death in systemic lupus erythematosus. An analysis of 249 cases. J.A.M.A. (J. Am. Med. Assoc.). 227: 1399-1402.

2. Urowitz, M. B., A. A. M. Bookman, B. E. Koehler, D. A. Gordon, H. A. Smythe, and M. A. Ogryzlo. 1976. The bimodal mortality pattern of systemic lupus erythematosus. Am. J. Med. 60: 221-225.

3. Lee, P., M. B. Urowitz, A. A. M. Bookman, B. E. Koehler, H. A. Smythe, D. A. Gordon, and M. A. Ogryzlo. 1977. Systemic lupus erythematosus: a review of 110 cases with reference to nephritis, the nervous system, infections, aseptic necrosis and prognosis. Q. J. Med. 181: 1-32.

4. Staples, P. J., D. N. Gerding, J. L. Decker, and R. S. Gordon. 1974. Incidence of infection in systemic lupus erythematosus. Arthritis Rheum. 17: 1-10.

5. Jasin, H. E., J. H. Orozco, and M. Ziff. 1974. Serum heatlabile opsonins in systemic lupus erythematosus. J. Clin. Invest. 53: 343-353.

6. Brandt, L., and H. Hedberg. 1969. Impaired phagocytosis by peripheral blood granulocytes in systemic lupus erythematosus. Scand. J. Haematol. 6: 348-353.

7. Landry, M. 1977. Phagocyte function and cell-mediated immunity in systemic lupus erythematosus. Arch. Dermatol. 113: 147-154.

8. Zurier, R. B. 1976. Reduction of phagocytosis and lysosomal enzyme release from human leukocytes by serum from patients with systemic lupus erythematosus. Arthritis Rheum. 19: 73-78.

9. Goetzl, E. J. 1976. Defective responsiveness to ascorbic acid of neutrophil random and chemotactic migration in Felty's syndrome and systemic lupus erythematosus. Ann. Rheum. Dis. 35: 510-515.

10. Clark, R. A., H. R. Kimball, and J. L. Decker. 1974. Neutrophil chemotaxis in systemic lupus erythematosus. Ann. Rheum. Dis. 33: 167-172.
11. Stossel, T. P. 1975. Phagocytosis: recognition and ingestion. Semin. Hematol. 12: 83-114.

12. Ward, P. A., and L. J. Newman. 1969. A neutrophil chemotactic factor from human C5. J. Immunol. 102: 93-99.

13. Snyderman, R., J. K. Phillips, and S. E. Mergenhagen. 1971. Biological activity of complement in vivo. Role of C.5 in the accumulation of polymorphonuclear leukocytes in inflammatory exudates. J. Exp. Med. 134: 1131-1143.

14. Cohen, A. S., W. E. Reynolds, E. C. Franklin, J. P. Kulka, M. M. Ropes, L. E. Shulman, and S. L. Wallace. 1971. Preliminary criteria for the classification of systemic lupus erythematosus. Bull. Rheum. Dis. 21: 643-648.

15. Goldstein, I., S. Hoffstein, J. Gallin, and G. Weissmann. 1973. Mechanisms of lysosomal enzyme release from human leukocyte: microtubule assembly and membrane fusion induced by a component of complement. Proc. Natl. Acad. Sci. U. S. A. 70: 2916-2920.

16. Gallin, J. I., and A. S. Rosenthal. 1974. The regulatory role of divalent cations in human granulocyte chemotaxis. Evidence for an association between calcium exchanges and microtubule assembly. J. Cell Biol. 62: 594-609.

17. Lowry, O. H., N. J. Rosebrough, A. L. Farr, and R. J. Randall. 1951. Protein measurement with the Folin phenol reagent. J. Biol. Chem. 193: 265-275.

18. Schiffmann, E., B. A. Corcoran, and S. M. Wahl. 1975. $\mathrm{N}$-Formylmethionyl peptides as chemoattractants for leukocytes. Proc. Natl. Acad. Sci. U. S. A. 79: 1059-1062.

19. Showell, H. J., R. J. Freer, S. H. Zigmond, E. Schiffman, S. Aswanikumar, B. Corcoran, and E. L. Becker. 1976. The structure-activity relations of synthetic peptides as chemotactic factors and inducers of lysosomal enzyme secretion for neutrophils. J. Exp. Med. 143: 1154-1169.

20. Ward, P. A., I. A. Lepow, and L. J. Newman. 1968. Bacterial factor chemotactic for polymorphonuclear leukocytes. Am. J. Pathol. 52: 725-736.

21. Zigmond, S., and J. G. Hirsch. 1973. Leukocyte locomotion and chemotaxis: new methods for evaluation and demonstration of a cell-derived chemotactic factor. J. Exp. Med. 137: 387-410.

22. Keller, H. U., M. W. Hess, and H. Cottier. 1977. The chemokinetic effect of serum albumin. Experientia (Basel). 33: 1386-1387.

23. Goldstein, I. M., M. Brai, A. G. Osler, and G. Weissmann. 1973. Lysosomal enzyme release from human leukocytes: mediation by the alternate pathway of complement activation. J. Immunol. 111: 33-37.

24. Brittinger, G., R. Hirschhorn, S. D. Douglas, and G. Weissmann. 1968. Studies on lysosomes. XI. Characterization of a hydrolase-rich fraction from human lymphocytes. J. Cell Biol. 37: 394-411.

25. Wacker, W. E. C., D. D. Ulmer, and B. L. Vallee. 1956. Metalloenzymes and myocardial infarction. II. Malic and lactic dehydrogenase activities and zinc concentration in serum. N. Engl. J. Med. 255: 449-456.

26. Craddock, P. R., J. G. White, and H. S. Jacob. 1978. Potentiation of complement (C5a)-induced granulocyte aggregation by cytochalasin B. J. Lab. Clin. Med. 91: 490-499.

27. Craddock, P. R., D. Hammerschmidt, J. G. White, A. P. Dalmasso, and H. S. Jacob. 1977. Complement (C.5a)induced granulocyte aggregation in vitro. J. Clin. Invest. 60: $260-264$.

28. Boyum, A. 1968. Isolation of mononuclear cells and granulocytes from human blood: isolation of mononuclear cells by one centrifugation, and of granulocytes by combining centrifugation and sedimentation at $\mathrm{lg}$. Scand. J. Clin. Lab. Invest. 21 (suppl. 97): 77-89.

29. Goldstein, B. D. 1974. Production of paroxysmal noc- 
turnal haemoglobinuria-like red cells by reducing and oxidizing agents. Br. J. Haematol. 26: 49-57.

30. Goldstein, I. M., and G. Weissmann. 1974. Generation of C5-derived lysosomal enzyme-releasing activity (C5a) by lysates of leukocyte lysosomes. J. Immunol. 113: 1583-1588.

31. Berenberg, J. L., and P. A. Ward. 1973. The chemotactic factor inactivator in normal human serum. J. Clin. Invest. 52: $1200-1206$.

32. Till, G., and P. A. Ward. 1975. Two distinct chemotactic factor inactivators in human serum. J. Immunol. 114: 843-847.

33. Ward, P. A., and J. Ozols. 1976. Characterization of the protease activity in the chemotactic factor inactivator. $J$. Clin. Invest. 58: 123-129.

34. Smith, C. W., J. C. Hollers, E. Dupres, A. S. Goldman, and R. A. Lord. 1972. A serum inhibitor of leukotaxis in a child with recurrent infections. J. Lab. Clin. Med. 79: 878-885.

35. Maderazo, E. G., P. A. Ward, C. L. Woronick, and R. Quintilliani. 1977. Partial characterization of a celldirected inhibitor of leukotaxis in human serum. $J$. Lab. Clin. Med. 89: 190-199.

36. Van Epps, D., and R. C. Williams. 1976. Suppression of leukocyte chemotaxis by human IgA myeloma components. J. Exp. Med. 144: 1227-1242.

37. Maderazo, E. G., P. A. Ward, C. L. Woronick, J. Kubik, and A. C. DeGraff. 1976. Leukotactic dysfunction in sarcoidosis. Ann. Intern. Med. 84: 414-419.

38. Ward, P. A., and J. L. Berenberg. 1974. Defective regulation of inflammatory mediation in Hodgkin's disease. Supernormal levels of chemotactic factor inactivator. N. Engl. J. Med. 290: 76-80.

39. Maderazo, E. G., P. A. Ward, and R. Quintilliani. 1975. Defective regulation of chemotaxis in cirrhosis. J. Lab. Clin. Med. 85: 621-630.
40. Ward, P. A., S. Goralnick, and W. E. Bullock. 1976. Defective leukotaxis in patients with lepromatous leprosy. J. Lab. Clin. Med. 87: 1025-1032.

41. Fernandez, H. N., and T. E. Hugli. 1976. Partial characterization of human C5a anaphylatoxin. I. Chemical description of the carbohydrate and polypeptide portions of human C5a. J. Immunol. 117: 1688-1693.

42. Fernandez, H., P. Henson, and T. E. Hugli. 1976. A single scheme for C3a and C5a isolation and characterization of chemotactic behavior. J. Immunol. 116: 1732A. (Abstr.)

43. Chenoweth, D. E., and T. E. Hugli. 1978. Initial characterization of the human polymorphonuclear leukocyte (PMN) C5a receptor. J. Immunol. In press.

44. Nilsson, U. R., R. J. Mandle, Jr., and J. A. McConnellMapes. 1975. Human C3 and C5: subunit structure and modifications by trypsin and $\bar{C} \overline{42}-\mathrm{C} \overline{423}$. J. Immunol. 114: 815-822.

45. Minta, J. O., and D. P. Man. 1977. Cleavage of human C5 by trypsin: characterization of the digestion products by gel electrophoresis. J. Immunol. 119: 1597-1602.

46. Wissler, J. H., V. J. Stecher, and E. Sorkin. 1972. Biochemistry and biology of a leucotactic binary serum peptide system related to anaphylatoxin. Int. Arch. Allergy Appl. Immunol. 42: 722-747.

47. Beebe, D., S. Goralnick, C. Gerard, J. Ozols, and P. A. Ward. 1978. The C5 chemotactic fragment isolated from activated human serum. J. Immunol. In press.

48. Bokisch, V. A., and H. J. Müller-Eberhard. 1970. Anaphylatoxin inactivator of human plasma: its isolation and characterization as a carboxypeptidase. J. Clin. Invest. 49: 2427-2436.

49. Fernandez, H. N., P. M. Henson, A. Otani, and T. E. Hugli. 1978. Chemotactic response to human C3a and C5a anaphylatoxins. I. Evaluation of C3a and C5a leukotaxis in vitro and under simulated in vivo conditions. $J$. Immunol. 120: 109-115. 